\title{
ASSESSMENT OF ANTI-INFLAMMATORY ACTIVITY AND CYTOTOXICITY OF FREEZE DRIED HYDROALCOHOLIC EXTRACT OF BIDENS ANDICOLA ON ISOLATED NEUTROPHILS
}

\author{
VINUEZA D*, LÓPEZ E, ACOSTA K, ABDO S \\ Natural Products Laboratory, Science Faculty, Polytechnic School of Chimborazo, Panamericana Sur km 11/2, CP 060155, Riobamba \\ Ecuador. Email: drvinueza@espoch.edu.ec
}

Received: 07 February 2017, Revised and Accepted: 12 March 2017

\section{ABSTRACT}

Objective: The aim of this study was to evaluate anti-inflammatory activity and cytotoxicity in vitro of hydroalcoholic extract of Bidens andicola.

Methods: B. andicola hydroalcoholic extract was obtained from aerial parts of B. andicola, following a standardized methodology. Briefly, aerial parts of $B$. andicola were extracted with ethanol $70 \% \mathrm{v} / \mathrm{v}$ and defatted with $\mathrm{n}$-hexane, hydroalcoholic fraction was concentrated under controlled conditions in a rotary evaporator, and finally the residue was freeze-drying to obtain the hydroalcoholic extract of $B$. andicola. Anti-inflammatory activity and cytotoxicity assays were carried out using in vitro isolated neutrophils model using stable water-soluble tetrazolium salts.

Results and Conclusions: The in vitro anti-inflammatory assay on isolated neutrophils demonstrated that the hydroalcoholic extract showed antiinflammatory activity compared to aspirin, with inflammatory inhibition percent values of $80.138 \pm 0.729$ to hydroalcoholic extract of $B$. andicola and $82.117 \pm 0.762$ to aspirin, each tested in five replicates at the concentration of $200 \mathrm{ppm}$ of hydroalcoholic extract or reference.

Keywords: Anti-inflammatory, Cytotoxicity, Bidens andicola, Cell proliferation reagent, Water-soluble tetrazolium salts.

(c) 2017 The Authors. Published by Innovare Academic Sciences Pvt Ltd. This is an open access article under the CC BY license (http://creativecommons. org/licenses/by/4. 0/) DOI: http://dx.doi.org/10.22159/ajpcr.2017.v10i6.17574

\section{INTRODUCTION}

Bidens is a genus from which some species have been studied. Among them, Bidens pilosa and Bidens andicola are the main representatives of South America. B. pilosa Linn. var. radiata Sch. Bip., belonging to Asteraceae family is one variety of the B. pilosa species originated from South America and transmitted to China. Pharmacognostic and phytochemical studies showed the presence of phenylpropanoid glucosides, diterpenes, polyacetylenes, flavonoids, and flavone glycosides identified as bioactive components from this plant possessing a wide range of biological/ pharmaceutical activities such as antioxidant, antimicrobial, antiinflammatory, antiseptic, liver protective, blood pressure lowering, and hypoglycemic effects. B. pilosa is used in Traditional Chinese Medicine for the treatment of periappendicular abscess, which is usually due to primary appendicitis or probably caused by various pathological conditions: Inflammatory, infective, neoplastic, immunological, ischemic, and occlusive. This plant is also employed as a folk medicine and a major ingredient of herbal tea in Taiwan believed to be able to prevent inflammation and cancer. Recently, the protein extract from it was demonstrated to have an anticancer property against colorectal cancer and induce cell apoptosis of SW480 cells via the reactive oxidative species production and glutathione depletion [1].

The study of the traditional indigenous medical practices in Amazonia and Southern Brazil brought to light ethnomedicinal use of $B$. pilosa Linne (Asteraceae) to treat certain tumors. This plant is also known as an antitumor agent in Cuba and the Bahamas. B. pilosa is a widely occurring plant species in tropical regions and it has several popular names according to the place where it is found. In Brazil, it is generally known as Picão-preto and it is widely used as folk medicine by indigenous people to treat a variety of illnesses including pain, fever, angina, diabetes, edema (water retention), infections, and inflammation. In addition, in the Amazon and South Brazil regions, infusion and hydroalcoholic solutions of B. pilosa are also regarded as useful in the treatment of malaria and even tumors. Furthermore, B. pilosa is a popular ingredient in herb teas in China. Phytochemical analyses of $B$. pilosa revealed a broad chemical constitution, and it was previously believed that this fact could explain its wide use. The main compounds already isolated from the plant are polyacetylenic and flavonoid substances. Polyacetylenes are hydrocarbons that strongly absorb long-wave ultraviolet radiation, and their medicinal activity is altered on exposure to light (photo activation). They have been reported to possess cytotoxic effects on parasites and modified cells in culture. The specific flavonoids present in Bidens have not been fully elucidated, although luteolin, quercetin and some others have been isolated so far. Interestingly, quercetin has been shown to suppress tumors in mice [2].

On the other hand, B. andicola is a native and an vegetal species, named amor seco, chilipugio, pante amarillo, saitilla in Ecuador, Perú and Argentina $[3,4]$. This plant belongs to the Asteraceae family. B. andicola is a perennial herb [5] that grows spontaneously around of crop fields in a high quantity. A peruvian ethnobotanical survey research determined that $B$. andicola can to be used as anti-infectious, anti-inflammatory, diuretic, antipyretic, astringent, hepatic protector, renal and bladder calculi, cystitis, prostatitis, and laryngitis [4]. In addition, the traditional use of $B$. andicola against mouthful is referred in Argentina [3]. Research about B. andicola chemical composition identified compounds derived from quercetin 3-0-methyl ether and quercetin, specially glycoside type compounds [6]. Quercetin 3-0-methyl ether is a flavonoid reported such as antioxidant, anticancer, and anti-inflammatory on several cellular models $[7,8]$. This vegetal resource is widely used by the indigenous communities of Ecuador as dye, anti-flu, tonic and refreshener and it represents a good alternative to economy to the indigenous communities if its effectiveness and security are guaranteed. The aim of this research was to evaluate anti-inflammatory activity and cytotoxicity in vitro of hydroalcoholic extract of $B$. andicola, as a way of rescuing and validate the ancestral wisdom of indigenous people who use this natural resource to treat their illnesses. 


\section{METHODS}

\section{Plant material}

B. andicola sample was collected in Ecuador, Chimborazo Province, San Andrés town, sector S $01^{\circ} 34^{\prime} 28.065^{\prime \prime}$ W $078^{\circ} 42^{\prime} 59.681^{\prime \prime}$, average height: $3124 \mathrm{~m}$. The plant material was taxonomically identified by a botanist Jorge Caranqui at Escuela Superior Politécnica de Chimborazo, and a specimen was deposited at Herbarium. The B. andicola aerial parts were collected, and the hydroalcoholic extract was obtained for use in the study.

\section{Reagents}

Ficoll-paque, modified Hank's solution, Zimosan A and Triton X-100 was purchased from Sigma-Aldrich, S.L. (USA), water-soluble tetrazolium salt (WST-1) from Roche (USA), aspirin from J.T. Baker (USA), dimethyl sulfoxide (DMSO) and ammonium chloride from Merck (Germany), deionized water was used in all experimental procedures. All other reagents were of analytical or high-performance liquid chromatography grade as appropriate.

\section{Equipment}

Heidolph Hei-VAP Advantage Rotary Evaporator (Germany), Micro Modulyo Freeze dryer - 1.51 Thermo (USA), Multiskan ${ }^{\mathrm{TM}}$ GO Microplate Spectrophotometer Thermo Scientific ${ }^{\mathrm{TM}}$ (USA), Branson 2510DTHSonicator, Vortex GemmyVM300 (Taiwan).

\section{Hydroalcoholic extract obtention}

Ultrasound-assisted extraction is a rapid technique that can also be used with mixtures of in miscible solvents. The hexane phase concentrated less polar compounds, while the aqueous alcohol phase concentrated polar flavonoids [9].

B. andicola hydroalcoholic extract was obtained from aerial parts (leaves, flowers, and stems) following a standardized methodology. From $10 \mathrm{~g}$ of aerial parts of $B$. andicola were extracted with ethanol $70 \% \mathrm{v} / \mathrm{v}$, sonicated for 15 minutes, follow by vortex for 15 minutes and finally defatted with $\mathrm{n}$-hexane. Hydroalcoholic fraction was concentrated under controlled conditions $\left(50^{\circ} \mathrm{C},-0.5 \mathrm{bar}\right)$ in a rotary evaporator, and finally, the aqueous residue was freeze-drying to obtain the hydroalcoholic extract of $B$. andicola.

\section{Preliminary phytochemical screening test for $\boldsymbol{B}$. andicola}

Phytochemical screening of the plant extract was carried out to investigate the presence of secondary metabolites such as flavonoids, terpenoids, saponins, tannins, and phenols using standard procedure [10].

\section{Total flavonoids determination}

The total flavonoids were measured by a colorimetric assay modified by Boukhris et al. (2012). $1 \mathrm{~mL}$ aliquot of the appropriately diluted sample or standard solution of quercetin $(20,40,60,80$, and $100 \mathrm{mg} / \mathrm{L})$ was added to a $10 \mathrm{~mL}$ volumetric flask containing $4 \mathrm{~mL}$ of $\mathrm{H}_{2} \mathrm{O}$. At zero time, $0.3 \mathrm{~mL}$ of $\mathrm{NaNO}_{2}(5 \%, \mathrm{w} / \mathrm{w})$ was added to the flask. After 5 minutes, $0.3 \mathrm{~mL} \mathrm{AlCl}{ }_{3}(10 \%, \mathrm{w} / \mathrm{w})$ was added. At 6 minutes, $2 \mathrm{~mL}$ of $\mathrm{NaOH}(1$ M) was added to the mixture. Immediately, the reaction flask was diluted to volume with the addition of $2.4 \mathrm{~mL}$ of $\mathrm{H}_{2} \mathrm{O}$ and thoroughly mixed. The absorbance of the mixture, characterized by a pink color, was determined at $510 \mathrm{~nm}$ compared to a water control. The total flavonoids were expressed as dry weight $\mathrm{mg} / \mathrm{g}$ quercetin equivalents (QE) [11]. For quercetin, the curve absorbance against concentration was described by the equation $y=0.0012 x+0.0218\left(R^{2}=0.9991\right)$.

\section{Total phenolics determination}

The total phenol content of extracts was determined using the phenol reagent (Boukhris et al., 2010) with few modifications in the sample volume. Briefly, $2 \mathrm{~mL}$ aliquot of the extract was assayed with $500 \mu \mathrm{L}$ of phenol reagent and $500 \mu \mathrm{L}$ of aqueous sodium carbonate $(20 \%, \mathrm{w} / \mathrm{v})$. The mixture was vortexed and diluted with water to a final volume of $5 \mathrm{~mL}$. After incubation for 30 minutes at room temperature, the absorbance was measured at $765 \mathrm{~nm}$. The total phenols were expressed as gallic acid equivalents (GAE/g of dry weight), using a calibration curve of a freshly prepared gallic acid solution [11]. For the gallic acid, the curve absorbance versus concentration is described by the equation $\mathrm{y}=0.0012 \mathrm{x}-0.0345\left(\mathrm{R}^{2}=0.9997\right)$.

\section{Isolation of human neutrophils}

Heparinized fresh venous blood sample was drawn from healthy volunteers and neutrophils were isolated [12]. Whole blood was added to Ficoll-paque, it was centrifuged for 30 minutes at $1500 \mathrm{rpm}$. After discarding the supernatant, red blood cells traces were lysed by mixing it with hypotonic ammonium chloride solution $(0.83 \%)$. It was centrifuged again, and the neutrophils were washed with modified Hank's solution (MHS), pH 7.4 and resuspended at concentration of $10^{7}$ cells/mL in a MHS appropriate volume [13].

\section{Cell viability assay}

Metabolically active cells reduce tetrazolium salts into colored formazan compounds. Therefore, tetrazolium salt-based colorimetric assays detect viable cells only. These sensitive assays can readily be performed in a microtiter plate with relatively few cells using modified method [14]. In this study, the human isolated neutrophils $\left(10^{7}\right.$ cells $\left./ \mathrm{mL}\right)$ were incubated with test compounds for 30 minutes then WST-1 $(250 \mu \mathrm{M})$ was added and incubated in shaking water bath at $37^{\circ} \mathrm{C}$ for $3 \mathrm{hr}$. The absorbance was measured at $450 \mathrm{~nm}$. Triton X-100 $(0.1 \%)$ was used as negative control showed $0.00 \%$ cell viability [13]. DMSO 5\% was used as positive control exhibited $100.00 \%$ cell viability. The OD is the mean of five replicates. Cell viability percent was calculated using the following formula and results are shown in Table 1.

$$
\% \text { Cellviability }=\frac{\mathrm{OD}}{\mathrm{OD}_{\mathrm{DMSO}}} \times 100
$$

\section{Anti-inflammatory assay}

Anti-inflammatory activity was determinated using modified assay [15]. This in vitro assay is based on the reduction of WST-1 in the presence of activated neutrophils. Anti-inflammatory assay was determinated in a total volume of $250 \mu \mathrm{L}$ MHS (pH 7.4) containing $10^{4}$ neutrophils $/ \mu \mathrm{L}$, $500 \mu \mathrm{M}$ WST-1 and various concentrations of test compounds. Control contained buffer, neutrophils, and WST-1. All compounds were equilibrated at $37^{\circ} \mathrm{C}$ and the reaction was initiated by adding opsonized Zymosan A (15 mg/mL), which was prepared by mixing it with human pooled serum, followed by centrifugation at $3000 \mathrm{rpm}$ and pallet was resuspended in phosphate buffer solution. Absorbance was measured at $450 \mathrm{~nm}$ [13]. Aspirin was used as a positive control that is widely used as nonsteroidal anti-inflammatory drugs for treatment of several inflammatory diseases $[16,17]$. $\mathrm{IC}_{50}$ values were calculated by comparing to the DMSO used as blank and expressed as produced superoxide anions inhibition percent.

\section{Statistical analysis}

All values are expressed as mean $\pm S D$. A value of $p<0.05$ was considered to indicate a significant difference. ANOVA test and Tukey's were performed to establish significant differences for multiple comparisons. Student's t-test was used to compare control group and the individual better performance treatment.

Table 1: Cell viability percent at different concentrations of extract

\begin{tabular}{ll}
\hline Concentration $(\mu \mathrm{g} / \mathrm{mL})$ & $\begin{array}{l}\text { Cell viability }(\%) \\
\text { B. andicola hydroalcoholic extract }\end{array}$ \\
\hline 200 & $27.679 \pm 0.329$ \\
100 & $30.399 \pm 0.372$ \\
50 & $32.959 \pm 0.474$ \\
25 & $36.639 \pm 0.262$ \\
\hline
\end{tabular}

B. andicola: Bidens andicola, SD was standard deviation of five replicates, SD: Standard deviation 


\section{RESULTS AND DISCUSSION}

$9.65 \mathrm{~g}$ of freeze-dried extract was obtained from $100 \mathrm{~g}$ of aerial parts of $B$. andicola. There is a relative high yield of extraction approximately $10 \%$. The preliminary phytochemical screening of hydroalcoholic extract revealed the presence of secondary metabolites such as flavonoids, phenols, and saponins; in addition, the presence of sugars; and in a little amount coumarins and catechins. These results are related with the previous research [6] that shown the presence of flavonol 7-0-glycosides with quercetin or quercetin 3-methyl ether as their aglycons and chalcone ester glycoside. The total flavonoid content of $B$. andicola expressed like QE/100 g of the plant was $9.987 \% \pm 0.123$, and total phenolics content of B. andicola expressed like GAE/100 g of the plant was $12.058 \% \pm 0.274$. These results suggest that $B$. andicola possess a high quantity of flavonoids and phenolic compounds in its composition. This is clearly established when $B$. andicola is compared with another Bidens species like Bidens biternata, in which the flavonoid content is in the range of $0.004-0.016 \%$ at different parts of the plant [18]. Nevertheless, B. pilosa total flavonoid content in the extracts measured using a colorimetric assay developed by Zhishen et al. (1999), was 66.2\% (w/w) [19], in another research in which B. andicola was fractionated by the use of solvents of increasing polarity, ethyl acetate extract of B. pilosa herb had the highest total flavonoid content $14.66 \%(\mathrm{w} / \mathrm{w})$, and methanolic extract had the highest phenolic content $7.61 \%(\mathrm{w} / \mathrm{w})[20]$. This meaning that B. andicola possesses an appreciable amount of flavonoids, without becoming as large as the case of B. pilosa. However, the phenol content of B. andicola in relation to $B$. pilosa is almost double.

Cell viability was determined using WST-1 metabolizing activity, a reliable method to this purpose and with multiple usefulness as in the case of the determination of decrease cytotoxicity induced by $\mathrm{H}_{2} \mathrm{O}_{2}$ of some subfractions of the red ginseng extract [21]. Table 1 shows the cell viability expressed by percentage. Cell viability decreases with increase the $B$. andicola hydroalcoholic extract concentration. There is a statistically significant difference between the B. andicola concentrations tested (ANOVA $\mathrm{p}<0.001$ ) and results differ from each other (TUKEY $\mathrm{p}<0.001$ ).

Table 2 shows the B. andicola hydroalcoholic extract anti-inflammatory activity percents. It demonstrated proportional relation with $B$. andicola hydroalcoholic extract concentrations, there is a statistically significant difference between the treatments (ANOVA $\mathrm{p}<0.001$ ) and results differ from each other (TUKEY $\mathrm{p}<0.001$ ) with the exception of aspirin that differs compared to the hydroalcoholic extract of $B$. andicola at $200 \mathrm{ppm}$ (TUKEY $\mathrm{p}<0.009$ ). Genus Bidens is widely studied for its biological activity and phytochemicals [22]. Medicinal properties of members of genus Bidens are due to polyacetylenic glycosides, aurons, auron glycosides, p-coumaric acid derivatives, flavonoids and flavonoid glycosides, sesquiterpenes, phenylpropanoid glucosides, and diterpenes [23,24]. These components would be responsible for its anti-inflammatory activity. Flavonoids have various biological activities, which are mainly related to its ability to inhibit enzymes and its effects on immune responses [25]. The pharmacological effects of quercetin, such as its antioxidant, anti-inflammatory, antiallergic, anti-aging, and anticancer activities, as well as its regulating effect on interleukin (IL)-6, IL-8, tumor necrosis factor, histamine, and tryptase release in mast cells, are well acknowledged [26].

Table 3 shows both responses anti-inflammatory activity and cell viability calculated at $200 \mu \mathrm{g} / \mathrm{mL}$ of $B$. andicola hydroalcoholic extract and aspirin. Results indicate that $B$. andicola hydroalcoholic extract has an appreciable anti-inflammatory activity. However, the extract does not achieve the same level of anti-inflammatory activity than aspirin ( $\mathrm{p}<0.003$ Student's $\mathrm{t}$-test). Nevertheless, the potential of $B$. andicola hydroalcoholic extract to its possible use like anti-inflammatory is evident. In the same way, cell viability comparison between $B$. andicola hydroalcoholic extract and aspirin differ from each other $(p<0.001$ Student's t-test). At a concentration of $200 \mu \mathrm{g} / \mathrm{mL}$, although the anti-
Table 2: Anti-inflammatory percent at different concentrations of extract

\begin{tabular}{|c|c|c|}
\hline Concentration $(\mu \mathrm{g} / \mathrm{mL})$ & \multicolumn{2}{|c|}{$\begin{array}{l}\text { Anti-inflammatory activity }(\%) \\
\text { B.andicola hydroalcoholic extract }\end{array}$} \\
\hline 200 & \multicolumn{2}{|l|}{$80.138 \pm 0.729$} \\
\hline 100 & \multicolumn{2}{|l|}{$76.999 \pm 0.695$} \\
\hline 50 & \multicolumn{2}{|l|}{$71.947 \pm 0.538$} \\
\hline 25 & \multicolumn{2}{|l|}{$66.827 \pm 1.225$} \\
\hline \multicolumn{3}{|c|}{$\begin{array}{l}\text { B. andicola: Bidens andicola. SD was standard deviation of five replicates, } \\
\text { SD: Standard deviation }\end{array}$} \\
\hline \multicolumn{3}{|c|}{$\begin{array}{l}\text { Table 3: Anti-inflammatory percent and cell viability values of } \\
\text { extract and positive control at } 200 \mu \mathrm{g} / \mathrm{mL}\end{array}$} \\
\hline \multirow[t]{2}{*}{ Components } & \multicolumn{2}{|c|}{ Responses at $200 \mu \mathrm{g} / \mathrm{mL}(\%)$} \\
\hline & $\begin{array}{l}\text { Anti-inflammatory } \\
\text { percent }\end{array}$ & Cell viability \\
\hline $\begin{array}{l}\text { B.andicola hydroalcoholic } \\
\text { extract }\end{array}$ & $80.138 \pm 0.729$ & $27.679 \pm 0.329$ \\
\hline Aspirin & $82.117 \pm 0.762$ & $23.359 \pm 0.504$ \\
\hline
\end{tabular}

B. andicola: Bidens andicola, SD was standard deviation of five replicates,

SD: Standard deviation

inflammatory percentage of aspirin differs from that of the extract, it is easy to deduce that $B$. andicola has a great potential as an antiinflammatory.

Around the world, genus Bidens has been used in traditional medicine as anti-inflammatory, antimalarial, antiulcer, antiallergic, anticancer, antidiabetic, and antibacterial agents [18]; in this sense, it can be determined that the ethnobotanical use from which we started have been validated at the level of the isolated neutrophils anti-inflammatory model.

\section{CONCLUSION}

Especially, the indigenous populations of the Sierra region of Ecuador have used B. andicola to treat their inflammatory diseases. The research carried out is a contribution so that the traditional use of this resource that is currently underutilized can become an opportunity for development of communities so that they maintain the ancestral use of the plant and can use it rationally to conserve it and in the future to take advantage of it to improve their economy.

\section{ACKNOWLEDGMENT}

Thanks to Escuela Superior Politécnica de Chimborazo to give facilities for development of this research.

\section{REFERENCES}

1. Wu J, Wan Z, Yi J, Wu Y, Peng W, Wu J. Investigation of the extracts from Bidens pilosa Linn. var. Radiata Sch. Bip. For antioxidant activities and cytotoxicity against human tumor cells. J Nat Med 2013;67(1):17-26

2. Kviecinski MR, Felipe KB, Schoenfelder T, de Lemos Wiese LP, Rossi MH, Gonçalez E, et al. Study of the antitumor potential of Bidens pilosa (Asteraceae) used in Brazilian folk medicine. J Ethnopharmacol 2008;117(1):69-75.

3. Hilgert NI. Plants used in home medicine in the Zenta River basin, Northwest Argentina. J Ethnopharmacol 2001;76(1):11-34.

4. Rehecho S, Uriarte-Pueyo I, Calvo J, Vivas LA, Calvo MI. Ethnopharmacological survey of medicinal plants in Nor-Yauyos, a part of the Landscape Reserve Nor-Yauyos-Cochas, Peru. J Ethnopharmacol 2011;133(1):75-85.

5. De-la-Cruz H, Vilcapoma G, Zevallos PA. Ethnobotanical study of medicinal plants used by the Andean people of Canta, Lima, Peru. J Ethnopharmacol 2007;111(2):284-94.

6. De Tommasi N, Piacente S, Pizza C. Flavonol and chalcone ester 
glycosides from Bidens andicola. J Nat Prod 1998;61(8):973-7.

7. Li J, Mottamal M, Li H, Liu K, Zhu F, Cho YY, et al. Quercetin-3methyl ether suppresses proliferation of mouse epidermal JB6 P cells by targeting ERKs. Carcinogenesis 2012;33(2):459-65.

8. Tseng HL, Li CJ, Huang LH, Chen CY, Tsai CH, Lin CN, et al. Quercetin 3-O-methyl ether protects FL83B cells from copper induced oxidative stress through the PI3K/Akt and MAPK/Erk pathway. Toxicol Appl Pharmacol 2012;264(1):104-13.

9. Andersen OM, Markham KR. Flavonoids: Chemistry, biochemistry and applications. Angewandte Chemie International Edition. Vol. 45. Boca Raton: Verlag Chemie; 2006. p. 1237.

10. Evans WW. Evans-Trease and Evans Pharmacognosy. $15^{\text {th }}$ ed. Edinburgh: Saunders; 2010.

11. Boukhris M, Simmonds MS, Sayadi S, Bouaziz M. Chemical composition and biological activities of polar extracts and essential oil of rose-scented geranium, Pelargonium graveolens. Phytother Res 2013;27(8):1206-13

12. Siddiqui RA, English D, Harvey K, Cui Y, Martin MI, Wentland J, et al. Phorbol ester-induced priming of superoxide generation by phosphatidic acid-stimulated neutrophils and granule-free neutrophil cytoplasts. J Leukoc Biol 1995;58(2):189-95.

13. Choudhary MI, Azizuddin, Jalil S, Atta-ur-Rahman. Bioactive phenolic compounds from a medicinal lichen, Usnea longissima. Phytochemistry 2005;66(19):2346-50.

14. Berridge MV, Tan AN, Mccoy KD, Wang RU. The biochemical and cellular basis of cell proliferation assays that use tetrazolium salts. Biochemica 1996;4:4-9. Available from: https://www.google.com. ec/url? $\mathrm{sa}=\mathrm{t} \& \mathrm{rct}=\mathrm{j} \& \mathrm{q}=\& \mathrm{esrc}=\mathrm{s} \&$ source $=$ web\& $\mathrm{cd}=1 \& \mathrm{cad}=\mathrm{rja} \& u a c t=$ $8 \&$ ved=0ahUKEwjyvoLpw_7RAhUL02MKHVI2AfEQFggdMAA \&url=https $\% 3 \mathrm{~A} \% 2 \mathrm{~F} \% 2 \mathrm{Fshop}$.roche.com $\% 2 \mathrm{Fwcsstore} \% 2 \mathrm{FRASCata}$ $\log$ AssetStore\%2FArticles\%2FBIOCHEMICA 964 p14-19.pdf\& usg=AFQjCNGw-cSecaV6Owi0WhPDzbb4bCrN3g.

15. Tan AS, Berridge MV. Superoxide produced by activated neutrophils efficiently reduces the tetrazolium salt, WST-1 to produce a soluble formazan: A simple colorimetric assay for measuring respiratory burst activation and for screening anti-inflammatory agents. J Immunol Methods 2000;238(1-2):59-68.

16. MacDonald TM, Beard K, Bruppacher R, Hasford J, Lewis M, Logan RF, et al. The safety of drugs for OTC use: What evidence is required for an NSAID switch? Pharmacoepidemiol Drug Saf 2002;11(7):577-84.
17. Martin C, Connelly A, Keku TO, Mountcastle SB, Galanko J, Woosley JT, et al. Nonsteroidal anti-inflammatory drugs, apoptosis, and colorectal adenomas. Gastroenterology 2002;123(6):1770-7.

18. Zahara K, Bibi Y, Tabassum S, Bashir T, Haider S, Araa A, et al. A review on pharmacological properties of Bidens biternata: A potential nutraceutical. Asian Pac J Trop Dis 2015;5(8):595-9. Available from: http://www.sciencedirect.com/science/article/pii/S2222180815608945.

19. Yuan LP, Chen FH, Ling L, Dou PF, Bo H, Zhong MM, et al. Protective effects of total flavonoids of Bidens pilosa L. (TFB) on animal liver injury and liver fibrosis. J Ethnopharmacol 2008;116(3):539-46.

20. Fidrianny I, Nadia E, Ruslan WK. In vitro antioxidant activities, total flavonoid, phenolic and carotenoid content from various extracts of four species Asteraceae herb. Int J Pharm Pharm Sci 2015;7(4):192-7. Available from: http://www.innovareacademics.in/journals/index.php/ ijpps/article/view/4626/8576.

21. Shin KY, Won BY, Ha HJ, Yun YS, Chang KA, Lee HG, et al. Ultrafiltrated fraction of Korean red ginseng extract improves memory impairment of tg2576 mice via inhibition of soluble $\mathrm{AB}$ production and acetylcholinesterase activity. Int J Pharm Pharm Sci 2016;8(4):272-7. Available from: http://www.innovareacademics.in/journals/index.php/ ijpps/article/view/10684/4929.

22. Brandão MG, Krettli AU, Soares LS, Nery CG, Marinuzzi HC. Antimalarial activity of extracts and fractions from Bidens pilosa and other Bidens species (Asteraceae) correlated with the presence of acetylene and flavonoid compounds. J Ethnopharmacol 1997;57(2):131-8

23. Bairwa K, Kumar R, Sharma RJ, Roy RK. An updated review on Bidens pilosa L. Der Pharm Chem 2010;2(3):325-37. Available from: http://www.search.ebscohost.com/login.aspx?direct=true \&db=aph\&A $\mathrm{N}=73827797$ \& site $=$ ehost-live.

24. Zulueta MC, Tada M, Ragasa CY. A diterpene from Bidens pilosa. Phytochemistry 1995;38(6):1449-50. Available from: http://www. sciencedirect.com/science/article/pii/003194229400793S.

25. Hollman PC, de Vries JH, van Leeuwen SD, Mengelers MJ, Katan MB. Absorption of dietary quercetin glycosides and quercetin in healthy ileostomy volunteers. Am J Clin Nutr 1995;62(6):1276-82.

26. Karuppagounder V, Arumugam S, Thandavarayan RA, Sreedhar R, Giridharan VV, Watanabe K. Molecular targets of quercetin with anti-inflammatory properties in atopic dermatitis. Drug Discov Today 2016;21(4):632-9. 